\title{
Pariwisata Halal Perspektif Ekonomi Syariah: Studi Takhrij Hadis
}

\author{
Wahyudin Darmalaksana*1, Busro \\ Fakultas Ushuluddin UIN Sunan Gunung Djati Bandung, Indonesia ${ }^{1,2}$ \\ Email: yudi_darma@uinsgd.ac.id
}

\begin{abstract}
This research is motivated by the tendency of a literal understanding of Islamic texts regarding compliance with halal tourism based on sharia economics. This study aims to analyze the text of the hadith, which is the basis for compliance with halal tourism from a sharia economic perspective. This study uses a qualitative approach through literature study by applying the takhrij hadith method, while the interpretation in the discussion of this study uses content analysis. The results of this study indicate that the hadith text, which is the basis for compliance with halal tourism from a sharia economic perspective, is of hasan quality because it can be applied as an Islamic practice. The discussion results explain that applying the text of hadith requires contextualization so that it does not narrow the concept of universal halal tourism with a sharia label, especially the necessity of sharia economics. This study concludes that Indonesia is a conducive country through moderate understanding that connects Islamic texts between universal values and local values to ensure that the homeland can become a centre for halal tourism destinations in the world.
\end{abstract}

Keywords: Economy; Hadith; Halal; Takhrij; Tourism.

\begin{abstract}
Abstrak
Penelitian ini dilatarbelakangi kecenderungan pemahaman literal terhadap teks Islam berkenaan dengan kepatuhan pariwisata halal berbasis ekonomi syariah. Penelitian ini bertujuan untuk menganalisis teks hadis yang menjadi dasar kepatuhan pariwisata halal perspektif ekonomi syariah. Penelitian ini menggunakan pendekatan kualitatif melalui studi pustaka dengan menerapkan metode takhrij hadis, sedangkan interpretasi dalam pembahasan penelitian ini digunakan analisis isi. Hasil penelitian ini menunjukan bahwa teks hadis yang menjadi dasar kepatuhan pariwisata halal perspektif ekonomi syariah berkualitas hasan dalam arti dapat diterapkan sebagai amalan Islam. Hasil pembahasan memaparkan bahwa penerapan teks hadis diperlukan kontekstualisasi sehingga tidak mempersempit konsep pariwisata halal yang bersifat universal dengan label syariah terlebih keharusan ekonomi syariah. Penelitian ini menyimpulkan bahwa Indonesia merupakan negara kondusif melalui paham moderat yang menghubungkan teks Islam di antara nilai-nilai universal dan nilai-nilai lokal sehingga memastikan tanah air dapat menjadi pusat destinasi pariwisata halal di dunia.
\end{abstract}

Kata Kunci: Ekonomi, Hadis, Halal, Pariwisata, Takhrij.

\section{A. PENDAHULUAN}

Pariwisata halal tengah menjadi isu internasional (Mafudi et al., 2021). Sektor pariwisata memainkan peran vital dalam ekonomi dunia sebagai kontributor lapangan kerja dan pertumbuhan ekonomi negara. Pada tahun 2020 target kontribusi pariwisata halal diproyeksikan menyumbang 35\% atau USD 300 juta ke sektor ekonomi global (Ramadhani, 2021). Pemerintah sangat mendorong pengembangan pariwisata halal di Indonesia (Mafudi et al., 2021). Sebagai penduduk dengan populasi mayoritas muslim terbesar di dunia, sehingga Indonesia berpeluang menjadi pusat destinasi dunia (Astuti, 2021). Juga pariwisata menjadi faktor pendukung pertumbuhan ekonomi di Indonesia yang dapat menyumbangkan devisa signifikan kepada Negara (Ramadhani, 2021). Kenyataannya, pariwisata halal berkembang pesat di Indonesia. Tren destinasi Indonesia terus mengalami peningkatan terutama pelancong dari Timur Tengah (Astuti, 2021). Bahkan, Indonesia dapat menampilkan keunggulan hingga

* Corresponding author

Received: July 22, 2021; Revised: August 20, 2021; Accepted: August 22, 2021 
terpilih menjadi destinasi pariwisata halal terbaik di dunia pada 2019 (Astuti, 2021). Indonesia dipilih sebagai negara yang unggul dalam pariwisata halal dibandingkan negara-negara muslim lain hingga dianugerahi penghargaan Global Muslim Travel Index (GMTI) tahun 2019 (Ramadhani, 2021).

Sungguhpun demikian, pariwisata halal Indonesia dipandang memiliki problem. Ada pandangan bahwa pariwisata halal Indonesia dinilai belum jelas dan masih lemah dalam aspek regulasi (Ramadhani, 2021) dan pada aspek terlepasnya pariwisata halal dengan penerapan ekonomi syariah (Basyariah, 2021). Terkait hal ini disebutkan bahwa Indonesia belum memiliki pengaturan secara khusus terkait pariwisata halal ini, kecuali perundang-undangan tentang kepariwisataan tahun 2009 (Ramadhani, 2021). Juga disebutkan bahwa praktik pariwisata halal pada dasarnya tidak bisa dilepaskan dari sistem ekonomi syariah (Basyariah, 2021). Sejumlah pakar menegaskan, perkembangan konsep pariwisata halal di Indonesia masih terfokus pada aspek teknis terkait pemenuhan sarana prasarana, seperti hotel syariah, jaminan makanan dan minuman di area restoran, dan transportasi bagi travelers wisata syar'i (Basyariah, 2021). Pandangan tentang perlunya pendekatan ekonomi syariah bagi kepatuhan pariwisata halal didasarkan hadis Nabi Saw. Pandangan ini menyatakan, aturan syariah berkonsekuensi terhadap hisab pada berbagai aktifitas dan perbuatan objek hukum yang kemudian harus dipertanggungjawabkan (Basyariah, 2021). Tentunya pandangan ini dinilai harfiah dalam memahami teks Islam (hadis). Oleh karena itu, penelitian ini memandang perlu dilakukan takhrij terhadap teks hadis yang diketahui telah dijadikan dasar pariwisata halal dalam perspektif ekonomi syariah.

Sejumlah pakar telah melakukan penelitian terdahulu terkait pariwisata halal berikut ekonomi syariah. Antara lain Basyariah, N. (2021), berjudul "Konsep Pariwisata Halal Perspektif Ekonomi Islam," yang diterbitkan pada Youth \& Islamic Economic. Penelitian ini bertujuan untuk mendeskripsikan dan menjelaskan konsep pariwisata halal dengan pendekatan sistem ekonomi syariah (Islam). Metode deskriptif eksploratif digunakan dalam penelitian ini untuk mendapatkan gambaran dan penjelasan yang lengkap dan fokus pada objek pariwisata halal dari perspektif ekonomi Islam. Penelitian ini menegaskan, pariwisata merupakan kegiatan ekonomi yang tidak dapat dipisahkan dari perilaku dan pelaku ekonomi, yang di dalamnya terdapat pelaku masyarakat sebagai konsumen, perusahaan sebagai penyedia jasa, dan negara sebagai regulator. Ekonomi Islam memandang semua kegiatan ekonomi tidak dapat dipisahkan dari tiga pilar konsep ekonomi Islam berupa pemilikan harta, pengelolaan dan pemanfaatan harta, dan pendistribusian harta. Sehingga konsep pariwisata halal harus membahas semua aspek dengan pendekatan tiga pilar ekonomi Islam, agar mendapatkan gambaran pariwisata halal yang komprehensif dari sudut pandang prinsip-prinsip pemilik barang dan jasa yang dikelola, model pengelolaannya, pelaksana pengelolaannya, dan sistem distribusinya di masyarakat (Basyariah, 2021). Adapun lanjutan dari penelitian ini berusaha melakukan kritik terhadap penerapan hadis yang dijadikan dasar dalam penelitian terdahulu.

Kerangka berpikir perlu dirancang sebagai alur logis yang menjadi peta konsep penelitian ini. Penelitian ini mendasarkan kontekstualisasi pada teks Islam (hadis), dimana hadis sebagai sumber Islam di samping al-Qur'an bukan dipahami secara tekstual, melainkan ditafsirkan sesuai situasi dan kondisi (Amrulloh, 2017; Pari, 2017; Syamsir, 2019). Mula-mula dilakukan kritik hadis untuk menguji otentisitas hadis dengan menggunakan metode takhrij (Darmalaksana, 2020b). Praktik Islam bersifat mengikat bila dilandasi hadis shahih (otentik) bukan dilandasi hadis dhaif(terisolir). Sebab, hadis shahih bersifat maqbul (diterima) sedangkan hadis dhaif bersifat mardud (tertolak), meskipun ada pula hadis shahih tetapi ghair ma'mul bih (tidak dapat diamalkan), karena alasan situasi dan kondisi (Soetari, 2005). Meskipun kualitas hadis dinilai shahih menurut pandangan kontekstualisasi tetap harus didialogkan dengan situasi dan kondisi terlebih lagi bila hadis tersebut bukan tentang masalah aqidah dan ibadah melainkan berkaitan dengan persoalan kehidupan sosial masyarakat, termasuk kehidupan ekonomi dan sektor pariwisata. Jelaslah pemahaman teks hadis dubutuhkan interpretasi kontekstual, yaitu memosisikan teks hadis di 
antara lokalitas dan universalitas (Pari, 2017). Berkaitan dengan kehidupan ekonomi dan pariwisata halal, hadis dituntut mampu berdialog dengan nilai-nilai universal yang berlaku di dunia intenasional dan dialog hadis dengan nilai-nilai lokal. Penelitian ini memahami kearifan lokal (local wisdom) selalu memiliki sisi universal serta berperan besar dalam menciptakan kebaikan bagi warga negara (Brata, 2016). Dengan demikian, hadis yang menjadi dasar kepatuhan pariwisata halal perspektif ekonomi syariah perlu didialogkan dengan aspek lokalitas di Indonesia dan aspek universalitas yang menjadi harapan warga dunia internasional.

Penelitian ini perlu menyajikan tinjauan pustaka sebagai landasan teori yang akan digunakan menjadi pisau analisis dalam pembahasan hingga ditarik kesimpulan. Di dunia ini berlangsung tiga mazhab dalam ekonomi syariah, yaitu iqtishaduna, mainstream, dan mazhab kritis (N. Pratiwi, 2021). Mazhab ini secara reduksional dapat dipetakan menjadi kelompok fundamental, kelompok moderat, dan kelompok liberal. Kelompok fundamental cenderung mendasarkan sisi kehidupan ekonomi pada teks Islam secara harfiah. Sedangkan kelompok moderat memahami teks secara kontekstual. Adapun kelompok liberal cederung mengabaikan teks dengan lebih memilih pemikiran liberalis. Secara garis besar terdapat dua pandangan tentang pariwisata halal berkaitan dengan ekonomi syariah. Pertama, pariwisata halal dipahami sebagai keharusan syariah termasuk penerapan ekonomi syariah sebagai kepatuhan pariwisata berlabel Islami (Basyariah, 2021). Kedua, pariwisata halal dipandang sebagai destinasi kesehatan dalam bentuk penyediaan hal-hal seperti makanan dan minuman, iklan sehat, dan pariwisata hijau yang memberikan perhatian terhadap perlindungan lingkungan ekologis secara praktis (Astuti, 2021). Pandangan terakhir ini lebih menghendaki eksplorasi kelayakan pengembangan ekologis daerahdaerah lokal sebagai tujuan utama destinasi pariwisata halal Indonesia (Mafudi et al., 2021).

Bedasarkan paparan di atas, formula penelitian disusun, yakni rumusan masalah, pertanyaan utama penelitian, tujuan penelitian, dan manfaat hasil penelitian. Rumusan masalah penelitian ini adalah terdapat hadis berkenaan dengan dalil kepatuhan pariwisata halal perspektif ekonomi syariah. Pertanyaan utama penelitian ini ialah bagaimana takhrij hadis tersebut berserta analisis sesuai dengan konteks pariwisata halal Indonesia. Penelitian ini bertujuan untuk menganalisis pariwisata halal pespektif ekonomi syariah dengan menerapkan metode takhrij hadis. Hasil penelitian ini diharapkan memiliki manfaat khususnya bagi pelaku ekonomi pariwisata halal di Indonesia.

\section{B. METODE PENELITIAN}

Penelitian ini menggunakan pendekatan kualitatif melalui studi kepustakaan (Darmalaksana, 2020a). Penelitian kualitatif ini menerapkan metode takhrij hadis sebagai lingkup ilmu hadis (Darmalaksana, 2020b). Sedangkan interpretasi dalam pembahasan penelitian ini digunakan analisis isi (Williamson et al., 2018). Analisis ini dilakukan dengan landasan horizon pengetahuan pariwisata halal dalam lingkup ekonomi syariah hingga ditarik kesimpulan penelitian.

\section{HASIL DAN ANALISIS}

Penelusuran hadis dilakukan dengan menggunakan aplikasi Ensiklopedi Hadis Kitab 9 Imam (Saltanera, 2015). Ditemukan hadis riwayat Tirmidzi No. 2341 Bab Hisab dan Qisas versi al-Alamiyah di bawah ini:

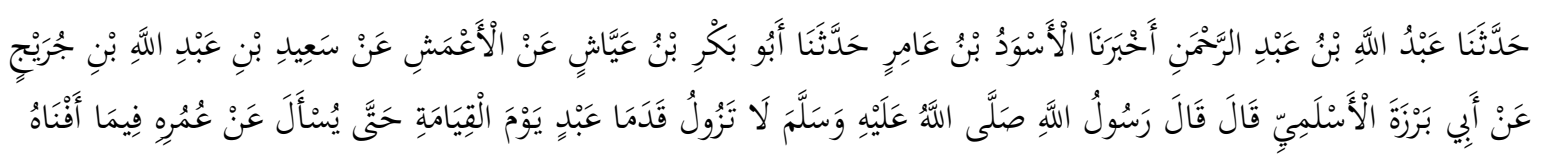




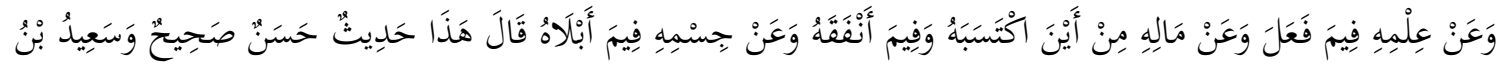

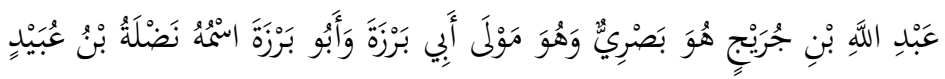

Telah menceritakan kepada kami Abdullah bin Abdurrahman telah menceritakan kepada kami AlAswad bin 'Amir telah mengabarkan kepada kami Abu Bakar bin Ayyasy dari Al-A'masy dari Sa'id bin Abdullah bin Juraij dari Abu Barzah Al-Aslami berkata, Rasulullah bersabda, "Kedua telapak kaki seorang hamba tidak akan bergeser pada hari kiamat sampai ditanya tentang umurnya untuk apa dia habiskan, tentang ilmunya untuk apa dia amalkan, tentang hartanya dari mana dia peroleh dan kemana dia infakkan dan tentang tubuhnya untuk apa dia gunakan." Dia berkata, Hadits ini hasan shahih, adapun Sa'id bin Abdullah bin Juraij dia adalah orang Bashrah dan dia adalah budak Abu Barzah, sedangkan Abu Barzah namanya adalah Nadlah bin 'Ubaid (HR. Tirmidzi No. 2341 Bab Hisab dan Qisas versi al-Alamiyah).

Tabel 1. Daftar Rawi dan Sanad

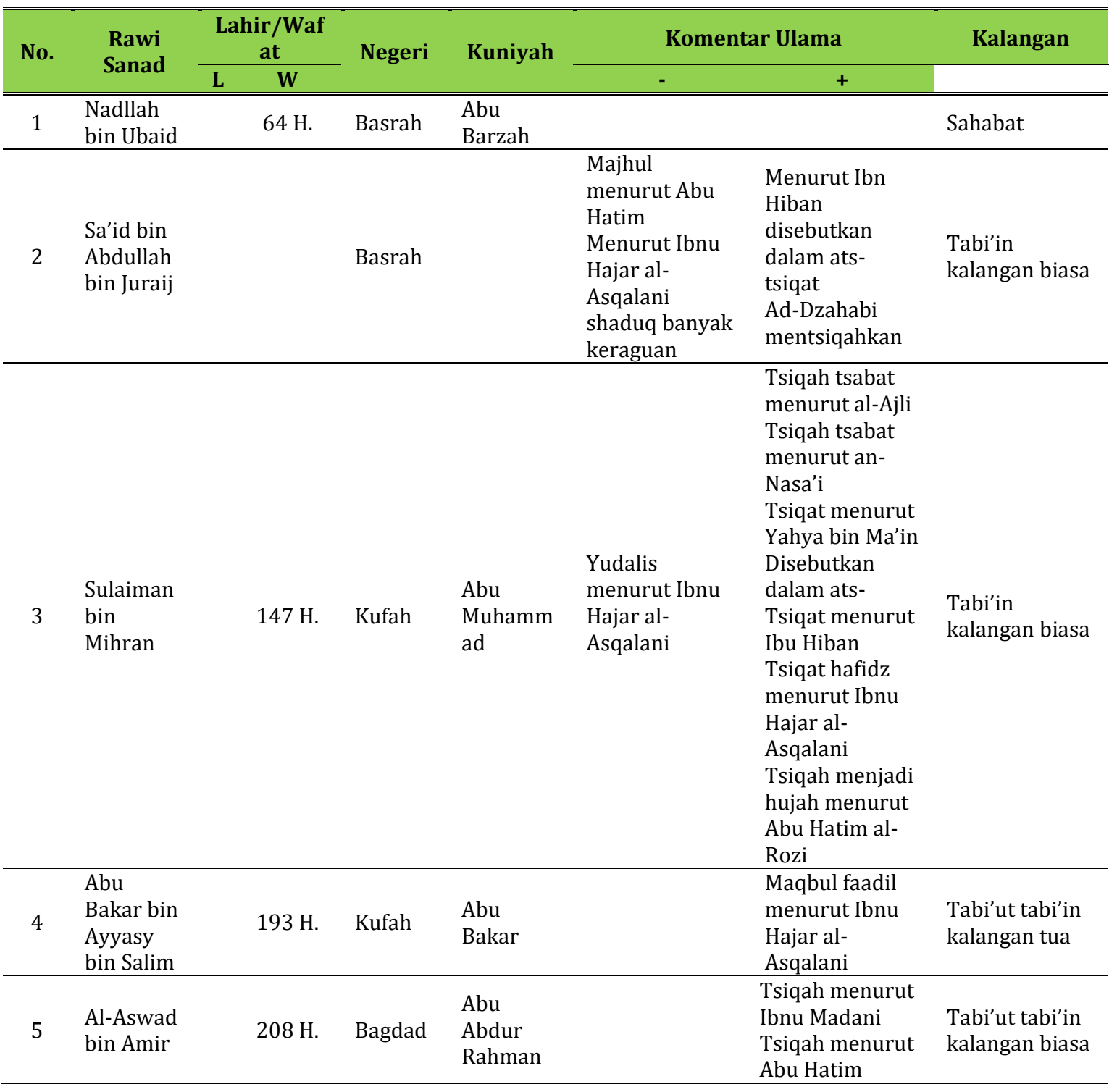




\begin{tabular}{|c|c|c|c|c|c|c|}
\hline & & & & & $\begin{array}{l}\text { La basa bih } \\
\text { menurut Yahaya } \\
\text { bin Ma'in } \\
\text { Salihul hadis } \\
\text { menurut Ibnu } \\
\text { Sa'd } \\
\text { Disebutkan } \\
\text { dalam al-Tsiqah } \\
\text { menurut Ibnu } \\
\text { Hiban } \\
\text { Tsiqah menurut } \\
\text { Ibnu Hajar al- } \\
\text { Asqalani }\end{array}$ & \\
\hline 6 & $\begin{array}{l}\text { Abdullah } \\
\text { bin Abdur } \\
\text { Rahman } \\
\text { bin al- } \\
\text { Fadlal bin } \\
\text { Birham }\end{array}$ & $255 \mathrm{H}$. & & $\begin{array}{l}\text { Abu } \\
\text { Muhamm } \\
\text { ad }\end{array}$ & $\begin{array}{l}\text { Tsiqah shaduk } \\
\text { menurut Abu } \\
\text { Hatim } \\
\text { Tsiqah mashur } \\
\text { menurut ad- } \\
\text { Daruqutni } \\
\text { Tsiqah menurut } \\
\text { Abu Bakar al- } \\
\text { Khatab } \\
\text { Hafidz mutqin } \\
\text { menurut Ibnu } \\
\text { Hibban } \\
\text { Tsiqah menurut } \\
\text { Ahmad bin } \\
\text { Hambal } \\
\text { Tsiqah fadil } \\
\text { mutqin hafidz } \\
\text { menurut Ibnu } \\
\text { Hajar al- } \\
\text { Asqalani } \\
\text { Hafidz menurut } \\
\text { ad-Dzahabi }\end{array}$ & $\begin{array}{l}\text { Tabi'ul atba } \\
\text { kalangan } \\
\text { pertengahan }\end{array}$ \\
\hline 7 & $\begin{array}{l}\text { Abu Isa } \\
\text { Muhamm } \\
\text { ad bin Isa } \\
\text { bin } \\
\text { Saurah at- } \\
\text { Tirmidzi }\end{array}$ & $279 \mathrm{H}$. & Tirmiz & $\begin{array}{l}\text { Imam } \\
\text { Tirmidzi }\end{array}$ & Ahli hadith & Mudawin \\
\hline
\end{tabular}

Tabel 1 adalah daftar rawi dan sanad hadis riwayat Tirmidzi No. 2341 pada Bab Hisab dan Qisas versi al-Alamiyah atau riwayat Tirmidzi No. 2417 versi Maktabatu al-Ma'arif Riyadh. Hadis ditranmisi dari Nabi Saw. oleh tujuh orang periwayat sejak mukharij bernama Nadllah bin Ubaid (64 H.) sebagai seorang sahabat sampai mudawin bernama Imam Tirmidzi (279 H.) sebagai seorang ahli hadis.

Hadis dinyatakan shahih bila sanad bersambung (muttasil) sejak mukharrij hingga mudawin (Darmalaksana, 2020b). Persambungan sanad dapat dilihat dari tahun lahir dan wafat para periwayat hadis. Pada Tabel 1 tampak Sa'id bin Abdullah bin Juraij tidak diketahui tahun, baik lahir maupun wafat. Akan tetapi, teori ilmu hadis dapat mengsumsikan masing-masing rawi kurang lebih berusia 90 tahun (Darmalaksana, 2020b). Sehingga dengan asumsi ini diperkirakan bertemu (liqa) antara guru (penyampai) dan murid (penerima) hadis. Dengan demikian, sanad hadis ini diprediksi bersambung (muttasil). Salah satu syarat hadis shahih lainnya ialah rawi harus adil dan dhabit (Darmalaksana, 2020b). Pada Tabel 1 tampak para ulama memberikan komentar positif ( $t a^{\prime} d i l$ ) terhadap para periwayat hadis, kecuali terdapat komentar negatif (jarh) terhadap Sa'id bin Abdullah bin Juraij dan Sulaiman bin Mihran. Dalam hal ini, rawi pertama dinilai majhul 
menurut Abu Hatim serta dinilai shaduq banyak keraguan menurut Ibnu Hajar al-Asqalani dan rawi kedua dinilai yudalis menurut Ibnu Hajar al-Asqalani (Saltanera, 2015). Majhul berarti tidak diketahui keberadaannya dan yudalis berarti kadang berdusta (Soetari, 1994), Karena terdapat penilaian negatif dari komentar ulama maka kualitas sanad hadis ini berstatus dhaif. Akan tetapi, derajat hadis dhaif dapat naik derajatnya menjadi status hasan li ghairihi bila terdapat syahid dan muttabi (Mardiana \& Darmalaksana, 2020). Adapun syahid adalah hadis lain sedangkan muttabi ialah periwayat lain (Soetari, 1994). Dari sisi keserupaan redaksi, hadis riwayat Tirmidzi No. 2341 dapat dijumpai pula pada hadis riwayat ad-Darimi No. 536 dan No. 538, dimana Husain Salim Asad ad-Darani menilai isnad riwayat adDarimi No. 536 sebagai hasan dan isnad riwayat ad-Darimi No. 538 dinilai dhaif (Saltanera, 2015). Berdasarkan hasil penelitian, kualitas sanad hadis ini hasan li ghairihi, meskipun Muhammad Nashiruddin al-Albani menilai sahih (Saltanera, 2015).

\section{Analisis Hasil}

Pemahaman literal terhadap teks Islam harus digeser ke interpretasi kontekstual. Basyariah, $\mathrm{N}$. (2021) melalui penelitian "Konsep Pariwisata Halal Perspektif Ekonomi Islam, sebagaimana disinggung terdahulu, melancarkan krtik bahwa perkembangan konsep pariwisata halal di Indonesia terbatas pada aspek teknis (Basyariah, 2021). Menurut Basyariah, N. (2021), konsep pariwisata halal di Indonesia belum mengembangkan ekonomi syariah, yang dalam hal ini berperan mengaitkan pemerintah, pengusaha, dan konsumen (Basyariah, 2021). Pandangan ini berarti menafikan penghargaan Indonesia sebagai pariwisata halal terbaik di tingkat dunia. Kenyataannya, Indonesia mengalahkan negara-negara muslim lain hingga dianugerahi penghargaan Global Muslim Travel Index (GMTI) pada tahun 2019 (Ramadhani, 2021). Ini membuktikan Indonesia dengan populasi penduduk muslim terbesar di dunia (Wibawa et al., 2021) memiliki keunggulan pada sektor pariwisata halal (Astuti, 2021; Ramadhani, 2021).

Hadis riwayat Tirmidzi No. 2341 pada Bab Hisab dan Qisas digunakan dasar oleh Basyariah, N. (2021) bagi konsep pariwisata halal menurut perspektif ekonomi Islam (Basyariah, 2021). Hadis ini dijadikan dasar bahwa aturan syariah ketika diterapkan ia memiliki konsekuensi hisab terhadap segala perbuatan umat manusia sebagai objek hukum serta segala perbuatan tersebut praktis kelak akan diminta pertanggungjawaban (Basyariah, 2021). Ada beberapa hal kritik yang hendak dilontarkan terhadap pandangan ini. Pertama, hendaknya hadis dilihat dari sebab wurud pada saat disabdakan oleh Nabi Saw. Berdasarkan hasil takhrij tampak kualitas hadis ini hasan li ghairihi, dalam arti dapat diamalkan sebagai hujjah Islam (Soetari, 1994), bahkan dinilai shahih oleh Muhammad Nashiruddin al-Albani (Saltanera, 2015), meskipun tidak sampai derajat masyhur (populer) terlebih mutawatir. Sebab, hadis ini hanya diriwayatkan Imam at-Tirmidzi dan ad-Darimi (Saltanera, 2015). Redaksi yang sama tidak ditemukan pada kitab-kitab hadis lain seperti sahih Bukhari dan Muslim. Ideal bila hadis dilihat dari sisi konteks situasi ketika disabdakan oleh Nabi Saw. (Lestari, 2015; Muin, 2015). Kedua, pemahaman hadis hendaknya dihasilkan melalui interpretasi secara kontekstual. Basyariah, N. (2021) melakukan kontekstualisasi hadis ini pada praktik kepatuhan pariwisata halal yang terintegrasi dengan ekonomi syariat Islam (Basyariah, 2021).

Terkait hal di atas, pembahasan ini perlu mengulas konsep pariwisata halal. Ada anggapan bahwa pariwisata halal berarti menerapkan asas Islam, hal ini sebagimana pandangan kelompok politik Islam. Pandangan ini kurang tepat karena dengan demikian pariwisata halal dalam arti asas Islam ia akan mendapat benturan dengan persoalan toleransi dengan pemeluk agama lain. Padahal, pariwisata halal bukan saja berlaku bagi umat beragama Islam melainkan berlaku pula bagi non-muslim (Wibawa et al., 2021). Pariwisata halal dalam arti asas Islam berarti bermakna pariwisata religi, bahkan lebih sempit lagi dari pariwisata religi yakni khusus bagi penganut Islam (Afghoni \& Busro, 2017). Pariwisata halal lebih luas dari pariwisata religi (Susilawati, 2019). Kembali ke makna pariwisata halal, yakni dipahami sebagai pariwisata kesehatan untuk menjamin pengunjung secara lebih baik (Astuti, 2021). Dengan demikian, pariwisata halal dalam pemahaman ini berlaku bagi seluruh 
umat beragama (Wibawa et al., 2021), karena seluruh ajaran agama menerapkan prinsip perilaku sehat, pelayanan sehat, dan fasilitas sehat.

Kecuali itu, ada istilah pariwisata halal berbasis syariat Islam (Astuti, 2021). Istilah ini berarti menghendaki didasarkannya syariat Islam dalam konsep pariwisata halal. Hal ini pada gilirannya akan terjebak pada istilahistilah, seperti kunjungan pendidikan Islam, rute ziarah, kolam renang muslim, bangunan tempat salat, area rekreasi panahan, dan lain-lain (Mafudi et al., 2021), bahkan hingga terdapat istilah hotel syariah (Halim \& Baroroh, 2021), travel syariah (Chrysnaputra \& Pangestoeti, 2021) dan karaoke syariah (Al Usrah et al., 2021). Kenyataan ini mengindikasikan sektor pariwisata halal dibawa ke segmentasi yang lebih sempit, dimana segmentasinya hanya lingkup pasar (market) umat beragama Islam. Alih-alih pariwisata halal perspektif ekonomi syariah, tidak disangsikan lagi bahwa pandangan pariwisata halal berbasis syariat Islam berarti menarik diri ke wilayah yang lebih sempit. Dengan demikian, penelitian Basyariah, N. (2021) tentang pariwisata halal perspektif ekonomi syariah berarti ia menghendaki pengertian yang sempit mengenai pariwisata halal.

Pariwisata halal pada dasarnya merupakan konsep universal (S. R. Pratiwi et al., 2018). Ia tumbuh seiring dengan konsep-konsep lain, seperti halal lifestyle (Adinugraha \& Sartika, 2019), halal food (Sthapit et al., 2021), halal cosmetic (Nur \& SAPIR, 2021), dan lain-lain. Teks Islam hendaknya selaras dengan konsepkonsep universal (Amrulloh, 2017; Pari, 2017; Syamsir, 2019) dalam arti tidak dibawa ke wilayah sempit yang dibatasi pandangan mazhab. Pun pula ekonomi syariah dalam ekspektasinya akan bergantung kelompok pemikiran. Kelompok "fundamental" biasanya bertabrakan dengan kelompok "liberal." Kelompok pertama menghendaki ekonomi syariah didasarkan teks Suci yakni al-Qur'an dan hadis melalui penalaran harfiah, literal, dan atau tekstual (Ahyani \& Slamet, 2021). Kelompok kedua cenderung mengabaikan teks dengan mengedepankan pandangan liberalis (Addiarrahman \& Yanti, 2020). Pertarungan dua mazhab pemikiran ini dapat ditengahi oleh paham moderat (Umam, 2020). Dalam hal ini, paham moderat Islam memahami teks Suci dengan menggali kandungan maksud-maksud teks (Hidayatullah, 2017). Kemudian maksud teks dihubungkan dengan situasi dan kondisi (Mustofa, 2020).

Ada pula pandangan bahwa regulasi pariwisata halal belum jelas dan masih lemah di Indonesia (Ramadhani, 2021). Terkait hal ini memang regulasi sangat penting. Di dalamnya akan mengatur kepatuhan bagi pengusaha, konsumen, dan aparatur terkait penerapan pariwisata halal. Tentunya Indonesia sebagai negara hukum membutuhkan regulasi pariwisata halal yang relevan. Namun, hal ini jangan terburu-buru karena bisa dijumpai prinsip-prinsip universal dalam aturan-aturan dunia internasional tentang pariwisata halal. Aturan-aturan dunia internasional ini dapat diakses bagi pengelolaan pariwisata halal di Indonesia. Sejalan dengan aturan-aturan dunia internasional, keunggulan lokal menjadi syarat penting dalam pembentukan regulasi. Semisal eksplorasi pariwisata ekologis di daerah-daerah lokal (Mafudi et al., 2021), hal ini memungkinkan Indonesia mampu menampilkan kekhasan dan keunggulan. Melalui eksplorasi maka Indonesia dapat menguatkan citra destinasi (Wibawa et al., 2021) sebagai pusat pariwisata halal dunia. Bagi dunia Islam syaratnya ialah upaya mendialogkan teks Suci antara lokalitas dan universalitas.

Pada 2020 telah ditargetkan sektor pariwisata halal untuk berkontribusi 35\% yakni setara USD 300 juta ke sektor ekonomi tingkat global (Ramadhani, 2021). Praktis keunggulan pariwisata halal di Indonesia akan berkontribusi besar terhadap devisa, lapangan kerja, dan pertumbuhan ekonomi negara tercinta. Pariwisata halal Indonesia perlu dipromosikan dengan upaya-upaya menjamin kepuasan bagi pengunjung mancanegara (Astuti, 2021). Adanya pandemi Covid-19 pasti sektor pariwisata halal terpukul, bahkan pukulan ini berlangsung di seluruh dunia (Maharani \& Ab Rahman, 2021). Namun, beberapa hal dapat dikembangkan semisal promosi pariwisata halal melalui aplikasi digital (Hakim, 2021). Saat ini merupakan momentum berbenah bagi dunia pariwisata halal di seluruh dunia, sehingga nanti ditemukan efektifitas pasca Covid-19 (Chrysnaputra \& Pangestoeti, 2021).

Bedasarkan paparan di atas, tegaslah pariwisata halal tidak perlu terkungkung label syariat secara sempit. Terlebih ada ide kepatuhan pariwisata halal ditekan dengan penerapan ekonomi syariah. Hal ini tidak perlu dalam 
arti tidak mendesak mengingat Indonesia telah berlangsung kondusif dengan peran Islam moderat sebagai direfresentasikan paham Ahlu Sunnah Wal Jamaah (Mufid, 2013). Aliran ini berusaha menghubungkan universalitas dan lokalitas di Indonesia (Muzakki, 2019; Umar, 2019). Dipahami bahwa local wisdom di samping berperan sebagai perekat bangsa (Brata, 2016), ia pun merupakan jaminan mewujudkan pariwisata halal khas Indonesia.

\section{SIMPULAN}

Hadis telah dijadikan dasar pandangan kepatuhan pariwisata halal dengan perspektif ekonomi syariah. Hadis ini melalui tinjauan takhrij hadis memiliki kualitas hasan dalam arti dapat diterapkan menjadi amalan Islam. Hanya saja diperlukan kontekstualisasi dalam penerapan teks hadis. Hal ini dalam rangka menghindari pemahaman hadis secara literal. Kontekstualisasi hadis berperan memosisikan hadis berada di tengah-tengah antara universalitas dan lokalitas. Dipahami bahwa pariwisata halal merupakan konsep universal. Aspek universal dipastikan tidak akan bertentangan dengan nilai-nilai kerarifan lokal. Indonesia sangat kaya dengan kearifan lokal sehingga berpeluang menjadi kekhasan dan keunggulan untuk menjadi pusat destinasi pariwisata halal di dunia internasional. Penelitian ini diharapkan memiliki implikasi manfaat khususnya bagi pengelolaan pariwisata halal di Indonesia. Penelitian ini memiliki keterbatasan tidak menemukan sebab wurud teks hadis yang dijadikan landasan kepatuhan pariwisata halal perspektif ekonomi syariah. Juga penelitian ini memiliki keterbatasan tanpa melakukan syarah hadis. Sehingga keterbatasan ini diharapkan menjadi peluang bagi penelitian lebih lanjut secara lebih mendalam di masa mendatang. Penelitian ini merekomendasikan kepada institusi pendidikan tinggi keagamaan Islam untuk mengembangkan interpretasi kontekstual dalam pemahaman teks Suci berkenaan dengan pariwisata halal. Juga merekomendasikan khususnya kepada pengelola pariwisata halal untuk mengeksplorasi dan mempromosikan kekhasan lokal sebagai keunggulan dalam rangka mengungkit Indonesia sebagai pusat destinasi dunia.

\section{Daftar Referensi}

Addiarrahman, A., \& Yanti, I. (2020). Dari Idealisme ke Pragmatisme: Pergeseran Paradigma dalam Pengembangan Hukum Ekonomi Syariah di Indonesia. Al-Manahij: Jurnal Kajian Hukum Islam, 14(2), 191-210.

Adinugraha, H. H., \& Sartika, M. (2019). Halal Lifestyle Di Indonesia. An-Nisbah: Jurnal Ekonomi Syariah, 5(2), 57-81.

Afghoni, A., \& Busro, B. (2017). Potensi Wisata Tradisi Syawalan di Makam Gunung Jati Cirebon. Jurnal Kepariwisataan: Destinasi, Hospitalitas dan Perjalanan, 1(2), 82-92.

Ahyani, H., \& Slamet, M. (2021). Respon Dunia Barat Terhadap Ekonomi Syariah Di Era Revolusi Industri 4.0. JPED (Jurnal Perspektif Ekonomi Darussalam)(Darussalam Journal of Economic Perspectives), 7(1), 23-44.

Al Usrah, C. R., Mutafarifa, B., \& Fahmi, M. F. (2021). Persepsi Muslim, Etika dan Nilai Bisnis dari Karaoke Syariah. Ar Rehla: Journal of Islamic Tourism, Halal Food, Islamic Traveling, and Creative Economy, 1(1), 47-62.

Amrulloh, A. (2017). Kontribusi M. Syuhudi Ismail dalam Kontekstualisasi Pemahaman Hadis. Mutawatir, 7(1), 76-104. https://doi.org/10.15642/mutawatir.2017.7.1.76-104

Astuti, D. (2021). Indonesia as the Best Halal Tourism Destination and its Impacts to Muslim's Travelers Visit. European Journal of Theology and Philosophy, 1(3), 43-50.

Basyariah, N. (2021). Konsep Pariwisata Halal Perspektif Ekonomi Islam. Youth \& Islamic Economic, 2(01s), 1-6.

Brata, I. B. (2016). Kearifan budaya lokal perekat identitas bangsa. Jurnal Bakti Saraswati (JBS), $5(1)$.

Chrysnaputra, R. D., \& Pangestoeti, W. (2021). Pariwisata Halal dan Travel Syariah Pasca Pandemi Covid 19. An-Nisbah: Jurnal Perbankan Syariah, 2(2), 151-167. 
Darmalaksana, W. (2020a). Metode Penelitian Kualitatif Studi Pustaka dan Studi Lapangan. PrePrint Digital Library UIN Sunan Gunung Djati Bandung.

Darmalaksana, W. (2020b). Prosiding Proses Bisnis Validitas Hadis untuk Perancangan Aplikasi Metode Tahrij. Jurnal Ushuluddin UIN Sunan Gunung Djati Bandung, 1, 1-7.

Hakim, L. (2021). Digitalisasi Wisata Halal Melalui Aplikasi Smartphone Dimasa Pendemi Covid-19. Journal Of Islamic Management, 1(2), 136-147.

Halim, A., \& Baroroh, N. (2021). Pariwisata Halal: Studi Komparatif Hotel Syariah di Yogyakarta dan Bali. Al-Manahij: Jurnal Kajian Hukum Islam, 15(1), 53-66.

Hidayatullah, K. (2017). Mazhab Ulama dalam Memahami Maqashid Syari'ah. Ulul Albab: Jurnal Studi Dan Penelitian Hukum Islam, 1(1), 1-19.

Lestari, L. (2015). Epistemologi Ilmu Asbab al-Wurud Hadis. Jurnal Studi Ilmu-Ilmu Al-Qur'an Dan Hadis, 16(2), 265-285.

Mafudi, M., Sugiarto, S., \& Praptapa, A. (2021). Emerging Opportunities for Halal Tourism in Rural Areas: Insights from Indonesia. Fokus Bisnis: Media Pengkajian Manajemen Dan Akuntansi, 20(1), 16-26.

Maharani, S., \& Ab Rahman, A. (2021). Virus Corona dan Dampaknya Terhadap Pariwisata Halal Dunia. Kodifikasia, 15(1).

Mardiana, D., \& Darmalaksana, W. (2020). Relevansi Syahid Ma'nawi dengan Peristiwa Pandemic Covid-19: Studi Matan Pendekatan Ma'anil Hadis. Jurnal Perspektif, 4(1), 12-19.

Mufid, A. S. (2013). Paham Ahlu Sunnah Wal Jama'ah dan Tantangan Kontemporer dalam Pemikiran dan Gerakan Islam di Indonesia. Harmoni, 12(3), 8-18.

Muin, M. (2015). Pemahaman Komprehensif Hadis Melalui Asbab Al-Wurud. Addin, 7(2).

Mustofa, I. (2020). Model Ijtihad Kolektif-Integratif: Upaya Pengembangan Fiqh Mu'amalah Kontekstual sebagai Landasan Pengembangan Produk Lembaga Bisnis Syariah. IAIN Metro.

Muzakki, H. (2019). Mengukuhkan Islam Nusantara: Kajian Sosiologis-Historis. An-Nuha: Jurnal Kajian Islam, Pendidikan, Budaya Dan Sosial, 6(2), 215-239.

Nur, I., \& SAPIR, A. S. M. D. (2021). Halal Cosmetic Awareness among College Students in Malaysia. International Journal of Business and Economic Studies, 3(1), 17-26.

Pari, F. (2017). Kontekstualitas Vs Universalitas Hadis: Problem Metodologi. Refleksi, 16(2), 187203.

Pratiwi, N. (2021). Aliran Pemikiran Ekonomi Islam Kontemporer. Center for Open Science.

Pratiwi, S. R., Dida, S., \& Sjafirah, N. A. (2018). Strategi komunikasi dalam membangun awareness wisata halal di kota Bandung. Jurnal Kajian Komunikasi, 6(1), 78-90.

Ramadhani, M. (2021). Dilema Regulasi Pariwisata Halal Di Indonesia. Journal of Islamic Tourism, Halal Food, Islamic Traveling, and Creative Economy, 1(1), 89-105.

Saltanera. (2015). Ensiklopedi Hadits Kitab 9 Imam. Lembaga Ilmu Dan Dakwah Publikasi Sarana Keagamaan, Lidwa Pusaka. https://store.lidwa.com/get/

Soetari, E. (1994). Ilmu Hadits. Amal Bakti Press.

Soetari, E. (2005). Ilmu Hadits: Kajian Riwayah dan Dirayah. Mimbar Pustaka.

Sthapit, E., Björk, P., \& Piramanayagam, S. (2021). Motivational, emotional and memorable dimensions of non-Muslim tourists' halal food experiences. Journal of Islamic Marketing.

Susilawati, C. (2019). Regulasi dan penerapan pariwisata halal di Indonesia. UIN Sunan Gunung Djati Bandung.

Syamsir, S. (2019). Kontekstualisasi Nilai-nilai Islam. Jurnal Media Intelektual Muslim Dan Bimbingan Rohani, 5(2).

Umam, A. K. (2020). Religiosity Memoderasi Pengaruh Reference Group Dan Consumer Attitude Terhadapbehavioral Intention Pada Bank Syariah: Perbandingan Antara Kelompok Islam Fundamentalis Dan Islam Moderat. UNIVERSITAS AIRLANGGA.

Umar, N. (2019). Islam Nusantara: Jalan panjang Moderasi Beragama di Indonesia. PT Elex Media Komputindo.

Wibawa, B. M., Pranindyasari, C., Bhawika, G. W., \& Mardhotillah, R. R. (2021). Discovering the importance of halal tourism for Indonesian Muslim travelers: perceptions and behaviors when traveling to a non-Muslim destination. Journal of Islamic Marketing. 
Williamson, K., Given, L. M., \& Scifleet, P. (2018). Qualitative data analysis. In Research Methods: Information, Systems, and Contexts: Second Edition. https://doi.org/10.1016/B978-0-08102220-7.00019-4 